\title{
Effect of timolol maleate on pacing induced myocardial ischaemia
}

\author{
KIERAN DALY, PETER J RICHARDSON, GEOFFREY BERGMAN, LYNNE ATKINSON, \\ STEVEN KERKEZ, DAVID E JEWITT
}

From the Department of Cardiology, King's College Hospital, London

SUMMARY The effects of timolol maleate administered intravenously on coronary and systemic haemodynamics, myocardial metabolism, and plasma catecholamine concentrations were assessed in 10 patients with confirmed coronary artery disease. Rapid atrial pacing to the onset of angina was performed in all patients. Timolol reduced cardiac output at rest and during pacing and reduced resting heart rate but did not affect arterial blood pressure. Left ventricular stroke work index fell during pacing. Coronary sinus blood flow was unchanged, but pulmonary artery diastolic pressure rose after timolol. The drug produced clinical improvement in nine of the 10 patients with prolongation of the mean pacing time to angina. There was evidence of improved myocardial metabolism with a change from production to extraction of lactate: Arterial noradrenaline concentrations at rest rose after timolol.

In these patients with coronary artery disease timolol produced an increased tolerance to atrial pacing stress, which appears to be due to a combination of effects including reduced myocardial contractility and decreased lipolysis.

The symptomatic benefits of beta adrenergic blocking agents in angina pectoris have resulted in their widespread use in patients with coronary artery disease. ${ }^{12}$ This beneficial role in the treatment of myocardial ischaemia has variously been attributed to the reduction of exercise induced increase in heart rate and systolic blood pressure, ${ }^{3}$ the reduction of myocardial contractility, ${ }^{4}$ the redistribution of coronary blood flows, ${ }^{5}$ and an effect on metabolic factors. ${ }^{6}$ There is considerable variance in published reports as to the relative importance of these mechanisms. More recently, these agents have been advocated in the treatment of survivors of myocardial infarction. ${ }^{78}$

Timolol maleate is a non-selective beta adrenergic blocking agent which has been shown to reduce mortality and reinfarction in patients surviving acute myocardial infarction, 9 and to reduce infarct size when given within four hours of the onset of chest pain. ${ }^{10}$ It is effective in the treatment of angina pectoris. ${ }^{11}$ Like other such agents, however, its precise mode of action has not been defined. This study examines the effect of acute timolol administration on

Requests for reprints to Dr K Daly, Regional Hospital, Galway, Ireland.

Accepted for publication 24 July 1984 haemodynamic and metabolic changes and circulating catecholamine concentrations in 10 patients with confirmed coronary heart disease.

\section{Patients and methods}

Ten patients with confirmed coronary artery disease and stable angina pectoris were studied. All had symptoms in the New York Heart Association function class II or III. ${ }^{12}$ Table 1 gives the details of individual patients. The patients had received no cardioactive drugs for at least $\mathbf{4 8}$ hours before the study and for 72 hours in the case of beta adrenergic blocking agents. None had renal or hepatic disease or clinical or radiological evidence of heart failure. Studies were performed after food and without premedication, and all patients were studied during normal sinus rhythm. In all cases written informed consent was obtained before the study, approval for the study having been obtained from the hospital ethical committee.

A Swan Ganz thermodilution catheter was positioned in the pulmonary artery for measurement of cardiac output and right atrial and pulmonary artery pressures. A thermodilution catheter (Wilton-Webster Laboratory) was placed in the mid- 
Table 1 Clinical characteristics of 10 patients with coronary artery disease

\begin{tabular}{|c|c|c|c|c|c|c|}
\hline Case No & $\begin{array}{l}\text { Age (yr) } \\
\text { and sex }\end{array}$ & $\begin{array}{l}\text { NYHA } \\
\text { class }\end{array}$ & $\begin{array}{l}\text { Coromary artery with luminal } \\
\text { stenosis }>75 \%\end{array}$ & Left ventricular function & $\begin{array}{l}\text { LVEF } \\
(\%)\end{array}$ & $\begin{array}{l}\text { LVEDP } \\
(\operatorname{man} H g)\end{array}$ \\
\hline $\begin{array}{r}1 \\
2 \\
3 \\
4 \\
5 \\
6 \\
7 \\
8 \\
9 \\
10\end{array}$ & $\begin{array}{l}64 M \\
64 M \\
46 M \\
63 M \\
54 M \\
49 M \\
56 M \\
52 M \\
54 M \\
58 M\end{array}$ & $\begin{array}{l}\text { II } \\
\text { II } \\
\text { III } \\
\text { III } \\
\text { II } \\
\text { III } \\
\text { II } \\
\text { II } \\
\text { II } \\
\text { III }\end{array}$ & $\begin{array}{l}\text { LAD } \\
\text { LAD, Cx, RCA } \\
\text { LAD, Cx } \\
\text { LAD, Cx, RCA } \\
\text { LAD } \\
\text { LAD, Cx, RCA } \\
\text { LAD } \\
\text { LAD } \\
\text { LAD } \\
\text { LAD, Cx, RCA }\end{array}$ & $\begin{array}{l}\text { Minor anterior wall hypokinesia } \\
\text { Anterior wall dyskinesia, inferior wall hypokinesia } \\
\text { Normal } \\
\text { Anterior and inferior wall hypokinesia } \\
\text { Anteroapical dyskinesia } \\
\text { Normal } \\
\text { Normal } \\
\text { Anterior wall hypokinesia } \\
\text { Normal } \\
\text { Anterior and inferior wall hypokinesia }\end{array}$ & $\begin{array}{l}70 \\
53 \\
72 \\
48 \\
58 \\
72 \\
69 \\
64 \\
72 \\
50\end{array}$ & $\begin{array}{r}4 \\
8 \\
4 \\
4 \\
12 \\
12 \\
4 \\
4 \\
10 \\
12\end{array}$ \\
\hline
\end{tabular}

NYHA, New York Heart Association ${ }^{12}$; LAD, left anterior descending; Cx, circumflex; RCA, right coronary artery; LVEF, left ventricular ejection fraction; LVEDP, left ventricular end diastolic pressure.

portion of the coronary sinus, its position confirmed by the injection of radio-opaque dye. This allowed measurement of coronary sinus blood flow by the continuous thermodilution method ${ }^{13}$ and also sampling of coronary venous blood. Arterial pressure was monitored and blood samples obtained through a 19 gauge needle positioned in the femoral artery. All pressures were measured with reference to the mid-chest and were recorded with an electrocardiogram on a Mingograph 82 recorder (Siemens). No heparin was given, and the catheters were flushed with saline.

After placement of the catheters the patients were permitted to rest for 20 minutes, and control haemodynamic measurements were then obtained. At the same time blood samples were withdrawn from the coronary sinus and femoral artery for later biochemical analysis. Atrial pacing was then started and the rate rapidly increased to $85 \%$ of maximum predicted heart rate for the individual patient. At the time of onset of angina, haemodynamic measurements were repeated and blood samples withdrawn before atrial pacing was stopped.

After a rest period of 20 minutes timolol maleate 2 mg was given intravenously over 10 minutes. After a further $\mathbf{2 0}$ minutes rest haemodynamic measurements and blood sampling were repeated. Atrial pacing was then restarted at the same rate as in the control period. At an equivalent time to that at which angina occurred during control, pacing measurements were repeated and then pacing continued to the onset of angina.

Arterial and coronary sinus blood samples were assayed for whole blood lactate, ${ }^{14}$ glucose, ${ }^{15}$ plasma free fatty acids, ${ }^{16}$ and noradrenaline. ${ }^{17}$ Whole blood oxygen and haemoglobin concentrations were measured using a radiometer OSM2 haemoximeter. Myocardial extraction ratios for each substrate were derived by dividing the arterial-coronary sinus difference by the arterial level expressed as a percentage.

STATISTICAL ANALYSIS

The data at rest and during pacing before and after timolol administration were compared with Student's $t$ test for paired data. Values are expressed as mean (SEM).

\section{Results}

\section{PACING TIME TO ANGINA}

All 10 patients experienced typical angina pectoris during control atrial pacing. After the administration of timolol the pacing time to angina was prolonged in nine patients and remained unchanged in one (Figure). The mean (SEM) pacing time to angina for the group increased from 199 (96) to $389(75) \mathrm{s}(\mathrm{p}<0.01)$.

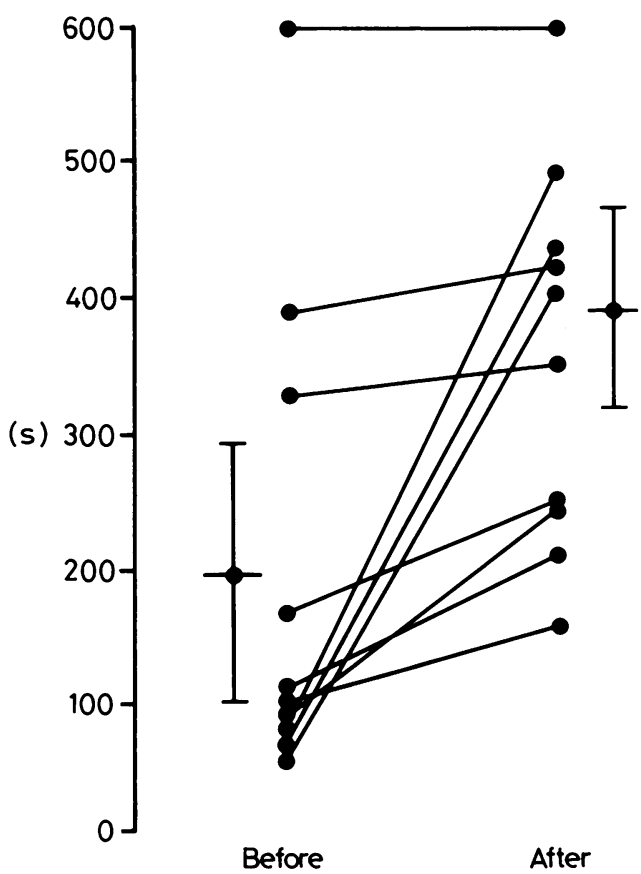

Figure Effect of timolol (2 mg intravenously) on pacing time to angina in 10 patients with coromary artery disease. Mean (SEM) value before timolol 199(96) s; after timolol $389(75) s(p<0.01)$. 
Table 2 Haemodynamic responses before and after timolol administration at rest and during atrial pacing in 10 patients. Values are mean (SEM)

\begin{tabular}{|c|c|c|c|c|}
\hline & \multicolumn{2}{|c|}{ Before (control) } & \multicolumn{2}{|l|}{ After } \\
\hline & Rest & Pacing & Rest & Pacing \\
\hline $\begin{array}{l}\text { Heart rate (beats/minute) } \\
\text { Arterial blood pressure (mm Hg): } \\
\text { Systolic } \\
\text { Diastolic } \\
\text { Pulmonary artery diastolic pressure (mm Hg) } \\
\text { Mean right atrial pressure (mm Hg) } \\
\text { Cardiac output (l/min) } \\
\text { Stroke volume (ml/beat) } \\
\text { Coronary sinus blood flow (ml/min) } \\
\text { Total systemic vascular resistance (units) } \\
\text { Coronary vascular resistance (units) } \\
\text { Stroke work index ( } \mathbf{m} \text { mer } \mathbf{m}^{2} \text { ) } \\
\text { Rate pressure product (mm } \mathbf{H g}_{\mathbf{g}} \text { beats/min) }\end{array}$ & $\begin{array}{l}71.3(2.6) \\
144.7(8) \\
72.4(3) \\
6.2(1) \\
3.7(0.6) \\
6.2(0.4) \\
87(5 \cdot 5) \\
143(13) \\
15.4(1) \\
0.7(0.1) \\
56(5 \cdot 7) \\
10.3(0.7)\end{array}$ & $\begin{array}{l}139(2.3) \\
145(6) \\
91(2.8) \\
13.6(3) \\
4.2(0.6) \\
6.7(0.4) \\
48(3) \\
226.7(17) \\
16.3(1.2) \\
0.5(0.05) \\
32.5(2.8) \\
20.2(0.8)\end{array}$ & $\begin{array}{l}64.6(1.5)^{\star \star \star} \\
144 \cdot 5(8) \\
73.7(4) \\
7.6(1)^{\star \star \star} \\
3.6(0.6) \\
5.3(0.4)^{\star \star} \\
83(5) \\
143.9(12) \\
18.1(1.5)^{\star} \\
0.7(0.07) \\
52 \cdot 2(4 \cdot 2) \\
9.4(0.6)^{\star \star}\end{array}$ & $\begin{array}{l}139(2.3) \\
141(6) \\
89(3) \\
13.4(2) \\
4.6(0.7) \\
5.6(0.3)^{\star \star \star \star} \\
41(2.4)^{\star \star \star \star} \\
209(12.9) \\
18.7(1.4)^{\star \star \star} \\
0.53(0.04) \\
26.6(2)^{\star \star \star} \\
19.6(0.8)\end{array}$ \\
\hline
\end{tabular}

Significance of changes with respect to control values: ${ }^{\star} \mathrm{p}<0.05, \star \star \mathrm{p}<0.02, \star \star \star \mathrm{p}<0.01, \star \star \star \star \mathrm{p}<0.001$.

\section{HAEMODYNAMIC RESPONSES}

After timolol administration heart rate fell at rest from $71.3(2.6)$ to $64.6(1.5)$ beats/minute (Table 2). No change in either systolic, diastolic, or mean arterial blood pressure occurred either at rest or during pacing with the drug. Right atrial pressure also remained unchanged. Pulmonary artery diastolic pressure, an indirect measurement of left ventricular end diastolic pressure, showed a small but significant rise at rest with the drug. There were no changes in the pacing values of this variable. Cardiac output fell significantly with the drug both at rest $(6.2(0.4)$ to $5.3(0.4) 1 / \mathrm{min}, \mathrm{p}<0.02)$ and during atrial pacing $(6.7(0.4)$ to $5.6(0.3) 1 / \mathrm{min}, \mathrm{p}<0.001)$. While a similar trend was seen in stroke volume only the pacing value was significantly less after the drug $(p<0.001)$. Although the expected increase in coronary sinus blood flow was seen between resting values and those at peak pacing, neither the resting nor pacing values were significantly changed by timolol. Similarly, coronary vascular resistance remained unchanged.
Total systemic vascular resistance rose both at rest (15.4 (1) to $18.1(1.5)$ units, $p<0.05)$ and during pacing $(16.3(1.2)$ to $18.7(1.4)$ units, $p<0.01)$ Stroke work index showed a small but insignificant fall at rest after timolol but fell significantly during pacing (32.5 (2.8) to $26.6(2) \mathrm{g} \mathrm{m}$ per m$\left.^{2}, \mathrm{p}<0.01\right)$. Owing to the effect of heart rate, the rate pressure product fell significantly at rest but not during pacing $(p<0.02)$.

\section{METABOLIC RESPONSES}

No significant change was seen in arterial lactate concentration after timolol, but the myocardial extraction ratio of lactate during pacing was significantly improved after the drug $(-26(16)$ to $7 \cdot 3(7.7) \%$, $P<0.05$ ) (Table 3). The arterial concentration of free fatty acids showed a trend towards reduction after the drug, although neither the resting nor pacing values were significantly different. A similar trend was seen for myocardial extraction of free fatty acids. Again, no significant changes in glucose arterial concentration or extraction ratios occurred. The coronary sinus oxygen

Table 3 Metabolic responses before and after timolol administration at rest and during atrial pacing in 10 patients. Values are mean $(S E M)$

\begin{tabular}{|c|c|c|c|c|}
\hline & \multicolumn{2}{|c|}{ Before (control) } & \multicolumn{2}{|l|}{ After } \\
\hline & Rest & Pacing & Rest & Pacing \\
\hline \multicolumn{5}{|l|}{ Lactate: } \\
\hline $\begin{array}{l}\text { Arterial concentration }(\mathrm{mg} / 100 \mathrm{ml} \text { ) } \\
\text { Myocardial extraction }(\%)\end{array}$ & $\begin{array}{l}5.9(0.8) \\
17.7(3.6)\end{array}$ & $\begin{array}{l}6.0(0.8) \\
-26.0(16)\end{array}$ & $\begin{array}{l}5.7(0.8) \\
14.4(3.9)\end{array}$ & $\begin{array}{l}6.4(0.9) \\
7.3(7.7)^{\star}\end{array}$ \\
\hline \multicolumn{5}{|l|}{ Free fatty acid: } \\
\hline $\begin{array}{l}\text { Arterial concentration (mmol/l) } \\
\text { Myocardial extraction (\%) }\end{array}$ & $\begin{array}{l}1 \cdot 1(0.1) \\
23 \cdot 8(4 \cdot 5)\end{array}$ & $\begin{array}{l}1 \cdot 2(0 \cdot 1) \\
25 \cdot 3(5 \cdot 5)\end{array}$ & $\begin{array}{l}0.9(0.08) \\
18 \cdot 3(8)\end{array}$ & $\begin{array}{l}0.9(0.1) \\
19.4(7 \cdot 1)\end{array}$ \\
\hline \multicolumn{5}{|l|}{ Glucose: } \\
\hline $\begin{array}{l}\text { Arterial concentration (mmol/1) } \\
\text { Myocardial extraction (\%) } \\
\text { Oxygen: }\end{array}$ & $\begin{array}{l}4.9(0.3) \\
3.9(2.4)\end{array}$ & $\begin{array}{l}4.8(0.4) \\
0.11(1.9)\end{array}$ & $\begin{array}{l}4.7(0.3) \\
0.5(1.6)\end{array}$ & $\begin{array}{l}5.1(0.4) \\
-0.3(2.7)\end{array}$ \\
\hline $\begin{array}{l}\text { Coronary sinus saturation (\%) } \\
\text { Myocardial consumption ( } \mathrm{ml} / \mathrm{min} \text { ) }\end{array}$ & $\begin{array}{l}25 \cdot 3(1 \cdot 5) \\
16 \cdot 3(1 \cdot 4)\end{array}$ & $\begin{array}{l}29.3(1.7) \\
25.4(1.9)\end{array}$ & $\begin{array}{l}27 \cdot 1(2 \cdot 1)^{\star \star} \\
14 \cdot 4(1 \cdot 3)\end{array}$ & $\begin{array}{l}28 \cdot 5(2 \cdot 2) \\
22.2(2 \cdot 2)\end{array}$ \\
\hline $\begin{array}{l}\text { Noradrenaline: } \\
\text { Arterial concentration (ng/l) }\end{array}$ & $241 \cdot 2(5 \cdot 8)$ & $163.5(36)$ & $357.8(98)^{\star}$ & $383.3(110)$ \\
\hline
\end{tabular}

Significance of changes with respect to control values: ${ }^{\star} p<0.05,{ }^{\star \star} p<0.02$.

Conversion: traditional to SI units-noradrenaline: $1 \mathrm{ng} \approx 5.91 \mathrm{pmol}$; lactate: $1 \mathrm{mg} \approx 0.01 \mathrm{mmol}$. 
saturation rose significantly at rest after the drug $(p<0.02)$, but no change was seen during pacing. Myocardial oxygen consumption fell slightly after the drug, but the small changes were not significant.

\section{CATECHOLAMINE RESPONSE}

The resting arterial noradrenaline concentration showed a rise after timolol from $241 \cdot 2(58)$ to $357 \cdot 8(98)$ $\mathrm{ng} / \mathrm{l}(1425.5(342.8)$ to $2114.6(579.2) \mathrm{pmol} / \mathrm{l})$ $(p<0.05)$. A similar but insignificant trend occurred during atrial pacing after the drug.

\section{Discussion}

Timolol maleate is a non-selective beta adrenergic blocking agent of proved efficacy in the treatment of angina pectoris ${ }^{11} 18$ and mild to moderate hyperten$\operatorname{sion}^{19}$ and in reducing mortality after myocardial infarction. ${ }^{9}$ Although similar in its properties to propranolol, except for its lack of membrane stabilising activity, it is less negatively inotropic than propranolol in a dose that produces equipotent beta adrenergic blockade. ${ }^{20}$ This study shows that in a group of patients with confirmed coronary artery disease, timolol increased tolerance to atrial pacing and improved myocardial metabolism. Such improvement could theoretically have been due to several effects attributable to beta blockade-namely, reduced myocardial oxygen consumption secondary to haemodynamic effects, changes in myocardial perfusion, or direct metabolic effects of the drug.

The rate pressure product is a sensitive index of the level of myocardial oxygen consumption. ${ }^{21}$ Whereas timolol reduced this at rest owing to a fall in heart rate, the pacing values for rate pressure product at the onset of angina were similar before and after the drug. Similarly, neither resting nor pacing values of arterial blood pressure were significantly changed. The other major determinants of myocardial oxygen demand are contractility and left ventricular wall tension. ${ }^{22}$ Although the study design did not allow direct measurement of these indices, cardiac output fell after timolol by approximately $16 \%$ with a significant fall in stroke volume on pacing $(p<0.001)$. These changes suggest a reduction in myocardial contractility. Such interpretation is open to criticism, especially in the face of a rise in systemic vascular resistance. This rise, however, was more likely to have been due to the baroreceptor reflex response to the fall in cardiac output rather than to blockade of vascular beta ${ }_{2}$ receptors, ${ }^{23}$ since a similar response has been shown for the beta $_{1}$ selective receptor blockers metoprolol and atenolol.

Despite the fall in resting heart rate, probable reduction in contractility both at rest and during pacing, and fall in left ventricular stroke work index on pacing myocardial oxygen consumption did not fall significantly in these patients after timolol. A small trend towards reduced oxygen consumption was seen, and this together with increased coronary sinus oxygen saturation at rest, despite unchanged coronary sinus blood flow, could be interpreted as indicating reduced oxygen demand. Similar studies with other beta adrenergic blocking agents ${ }^{64}$ have, however, failed to show reduced myocardial oxygen consumption despite improvement in symptoms and myocardial metabolism. It is likely that the benefits of decreased contractility are partially counterbalanced by the increase in left ventricular volume that occurs with these agents. This is supported by the small but significant rise in left ventricular filling pressure that occurred at rest after timolol.

No change in global coronary perfusion was seen after timolol. Although redistribution of blood flow to ischaemic areas of the myocardium has been suggested as a mode of action of beta blocking agents, ${ }^{5}$ this study did not include examination of such possible effects.

Beta blocking agents can partially inhibit both peripheral ${ }^{25}$ and myocardial ${ }^{26}$ lipolysis, lessen the inhibitory effect of fatty acids on myocardial pyruvate metabolism, and cause a preferential shift to metabolism of other substrates such as lactate. ${ }^{27}$ Such an effect has been suggested to contribute to the efficacy of propranolol ${ }^{6}$ and atenolol ${ }^{23}$ in the relief of angina. In this study, however, timolol caused a small but statistically insignificant fall in arterial concentration and myocardial extraction of free fatty acids. The extent of this fall is unlikely to completely explain the improvement in lactate metabolism but cannot be discounted as having made some contribution to the overall effect of the drug.

The resting plasma noradrenaline concentrations in these patients were similar to those previously described in ischaemic heart disease. ${ }^{28} \mathrm{~A}$ small rise in the arterial noradrenaline concentration was seen after timolol both at rest and during pacing, although the pacing values did not reach statistical significance. A similar increase in plasma noradrenaline has been described after propranolol both in ischaemic ${ }^{29}$ and hypertensive $^{30}$ patients and is probably the result of activation of the sympathoadrenal system by the decrease in cardiac output after beta blockade. Any potentially deleterious effect of this rise, such as increased lipolysis, appears to have been prevented by timolol.

The negative chronotropic effect of timolol maleate, as with other beta adrenergic blocking agents, is of prime importance in the prevention of exercise induced angina pectoris. In this atrial pacing study benefits other than that due to heart rate reduction were seen after the administration of intravenous timolol. The improvement in myocardial metabolism 
at an equivalent pacing time appears to be due to the combined effects of reduced contractility and decreased lipolysis brought about by the drug. The broad profile of this non-selective beta adrenergic blocking agent emphasises its role in the treatment of myocardial ischaemia in its various clinical situations.

We gratefully acknowledge the support of Merck, Sharp, and Dohme, the Voluntary Research Trust at King's College Hospital, and the research facilities of the Rayne Institute.

\section{References}

1 Epstein SE, Braunwald E. Inhibition of the adrenergic nervous system in the treatment of angina pectoris. Med Clin North Am 1968; 52: 1031-9.

2 Miller RR, Olson HG, Pratt CM, Amsterdam EA, Mason DT. Efficacy of beta adrenergic blockade in coronary heart disease: propranolol in angina pectoris. Clin Pharmacol Ther 1975; 18: 598-605.

3 Frishman WH, Kostis J, Strom J, et al. Clinical pharmacology of the new beta-adrenergic blocking drugs. Part 6. A comparison of pindolol and propranolol in treatment of patients with angina pectoris. The role of intrinsic sympathomimetic activity. Am Heart $\mathcal{f} 1979$; 98: 526-35.

4 Wolfsun S, Gorlin R. Cardiovascular pharmacology of propranlol in man. Circulation 1969; 40: 501-11.

5 Pitt B, Craven P. Effect of propranolol in regional myocardial blood flow in acute ischaemia. Cardiovasc Res 1970; 4: 176-9.

6 Armstrong PW, Chiong MA, Parker JO. Effects of propranolol on the hemodynamic, coronary sinus blood flow and myocardial metabolic response to atrial pacing. $A m \mathcal{F}$ Cardiol 1977; 40: 83-9.

7 Beta-blocker heart attack trial research group. National Heart, Lung and Blood Institute. A randomized trial of propranolol in patients with acute myocardial infarction I. Mortality results. FAMA 1982; 247: 1707-14.

8 Wilhelmsson C, Vedin JA, Wilhelmsen L, Tibblin G, Werkö L. Reduction of suddent deaths after myocardial infarction by treatment with alprenolol. Lancet 1974; ii: $1157-60$.

9 The Norwegian Multicenter Study Group. Timololinduced reduction in mortality and reinfarction in patients surviving acute myocardial infarction. $N$ Engl $f$ Med 1981; 304: 801-7.

10 The International Collaborative Study Group. Reduction of infarct size with the early use of timolol in acute myocardial infarction. $N$ Engl 7 Med 1984; 310: 9-15.

11 Harris FJ, Low RI, Paumer L, Amsterdam EA, Mason DT. Anti-anginal efficacy and improved exercise performance with timolol. Am $\mathcal{F}$ Cardiol 1983; 51: 13-8.

12 New York Heart Association Criteria Committee. Nomenclature and criteria for diagnosis of diseases of the heart and great vessels. 7th ed. Boston: Little, Brown, 1973: 286.

13 Ganz W, Tamura K, Marcus HS, Donoso R, Yoshida S, Swan HJC. Measurement of coronary sinus blood flow by continuous thermodilution in man. Circulation 1971; 44: 181-95.

14 Livesley B, Atkinson L. Accurate quantitative estimation of lactate in whole blood [Letter]. Clin Chem 1974; 20: 1478.

15 Mager M, Farese G. What is "true" blood glucose? A comparison of three procedures. Am $\mathcal{F}$ Clin Pathol 1965; 44: 104-8.

16 Lauwerys RR. Colorimetric determination of free fatty acids. Anal Biochem 1969; 32: 331-3.

17 Henry DP, Starman BJ, Johnson DG, Williams RH. A sensitive radioenzymatic assay for norepinephrine in tissues and plasma. Life Sci 1975; 16: 375-84.

18 Leary WP, Coleman AJ. The treatment of angina pectoris with Blockadren (timolol maleate MSD). In: Magnani $\mathrm{B}$, ed. Beta-adrenergic blocking agents in the management of hypertension and angina pectoris. New York: Raven Press, 1974: 139-46.

19 Harris FJ, Tonkin M, Pratt C, DeMaria AN, Amsterdam EA, Mason DT. Short and long-term therapy of mild essential hypertension with timolol. Clin Pharmacol Ther 1981; 30: 765-72.

20 Scriabrine A, Torchiana ML, Stavorski JM, Ludden CT, Minsker DH, Stone CA. Some cardiovascular effects of timolol, a new $\beta$-adrenergic blocking agent. (1) Arch Int Pharmacodyn Ther 1973; 205: 76-93.

21 Holmberg S, Varnauskas E. Coronary circulation during pacing-induced tachycardia. Acta Med Scand 1971; 190: 481-90.

22 Braunwald E. Control of myocardial oxygen consumption: physiologic and clinical considerations. $\mathrm{Am} \mathcal{f} \mathrm{Car}$ diol 1971; 27: 416-32.

23 Stobeck JE, Frishman WH, Sonnenblick EH. The haemodynamic effects of Pindolol in the treatment of systemic hypertension. Cardiovascular Reviews and Reports 1982; 3: 1844-60.

24 Thompson DS, Naqvi N, Juul SM, Coltart DJ, Jenkins BS, Webb-Peploe MM. Haemdynamic and metabolic effects of atenolol in patients with angina pectoris. $\mathrm{Br}$ Heart f 1980; 43: 668-79.

25 Deacon SP. The effects of atenolol and propranolol upon lipolysis. Br f Clin Pharmacol 1978; 5: 123-5.

26 Lech JJ, Jesmok GH, Calvert DN. Effects of drugs and hormones on lipolysis in the heart. Fed Proc 1977; 36: $2000-8$.

27 Pilkington TRE, Lowe RD, Foster R, et al. Effect of sympathomimetic compounds with beta adrenergic effects on plasma free fatty acids in man. $\mathcal{f}$ Lipid Res 1966; 7: 73-6.

28 Mueller HS, Rao PS, Rao PB, Gory DJ, Mudd JG, Ayres SM. Enhanced transcardiac 1-norepinephrine response during cold pressor test in obstructive coronary artery disease. Am $\mathcal{F}$ Cardiol 1982; 50: 1223-8.

29 Hansen JF, Hesse B, Christensen NJ. Enhanced sympathetic nervous activity after intravenous propranolol in ischaemic heart disease: plasma noradrenaline splanchnic blood flow and mixed venous oxygen saturation at rest and during exercise. Eur $\mathcal{F}$ Clin Invest 1978; 8: 31-6.

30 Rahn KH, Gierlichs HW, Planz G, Planz R, Schols M, Stephany $W$. Studies on the effects of propranolol on plasma catecholamine levels in patients with essential hypertension. Eur f Clin Invest 1978; 8: 143-8. 